\title{
Investigation of antibacterial properties of wool fabrics dyed with pine cones
}

\section{REZUMAT - ABSTRACT}

\section{Investigarea proprietăților antibacteriene ale țesăturilor din lână vopsite cu conuri de pin}

Tendințele în modă și culoarea reprezintă elementul primordial al primei etape de selecție a produselor textile. Acesta este motivul pentru care, în industria textilă, vopsirea are un mare succes. În special vopsirea naturală a dus la dezvoltarea de noi tendințe în ultima perioadă și a dobândit importanță în acest sens. În acest studiu, conurile de pin au fost utilizate pentru vopsirea țesăturilor din lână cu ajutorul a cinci agenți de mordansare diferiți și au fost realizate și vopsiri fără mordant. În plus, țesăturile din lână vopsite cu conuri de pin au fost evaluate din punctul de vedere al rezistenței la lumină și la spălare. S-a constatat că diferite culori și nuanțe pot fi obținute prin utilizarea unor agenți de mordansare și, în final, s-a observat că pot fi utilizate conurile de pin ca sursă de vopsire naturală. Mai mult decât atât, eficiența antibacteriană a probelor vopsite a fost investigată pentru a studia efectul sursei de colorant natural utilizat și al agenților de mordansare. S-a constatat că probele vopsite au proprietăți antibacteriene diferite în funcție de agentul de mordansare utilizat și de bacteriile analizate.

Cuvinte-cheie: lână, material textil, colorant natural, antibacterian, pin, con de pin

\section{Investigation of antibacterial properties of wool fabrics dyed with pine cones}

Fashion and color are the foreground of the case in the first stage of the selection of textile products. That is why coloring in textiles has a great appeal. In particular, natural dyeing, which has caught up with new trends in recent times, has gained importance in this regard. In this study, pine cones were used in dyeing of wool fabrics with the help of five different mordanting agent and also mordant-free dyeings were performed too. Besides, wool fabrics dyed with pine cones have been evaluated in terms of light and washing fastnesses. It was found that different colors and shades can be obtained with the use of different mordanting agents and finally it was observed that pine cones can be used as a natural dye source. Moreover the antibacterial efficiencies of the dyed samples were investigated to see the effect of the used natural dye source and the mordanting agents. It was seen that the dyed samples have different antibacterial properties depending on the used mordanting agent and the bacteria tested on.

Keywords: wool, textile, natural dye, antibacterial, pine, pine cone

\section{INTRODUCTION}

Color pervades all aspects of our lives, influencing our moods and emotions [1]. The coloring of textiles for value addition, look and desire of the customers was anciently initiated by using colors of natural source [2]. It is an ancient art and it was primitively managed by sticking plants to fabric or rubbing crushed pigments into cloth [3]. But the introduction of synthetic dyes led to an almost complete replacement of natural dyes because of the several advantages [4]. The effluents from finishing processes contain high concentrations of biologically difficult-todegrade or even inert auxiliaries and chemicals and there is pressure on dye manufacturers to develop dyes that can reduce environmental problems [5-6]. Because of the increased environmental awareness to avoid some hazardous synthetic dyes, the use of natural dyes has become a matter of significant importance [7]. In this respect this study was aimed to show the usability of pine cones for coloration of wools and the antibacterial efficiencies of the dyed samples. Anatolian black pine is one of the most common and important forest tree species in Turkey [8]. Pinus nigra belonging to Pinaceae family is grown in west and south regions of Anatolia [9]. Large quantities of pine cones are produced annually throughout the world, especially in pine plantations grown for the pulp and paper industry [10]. The antimicrobial activity is an important property for some functional fabrics [11]. The large surface area and the ability to retain moisture of textile structures enable microorganisms' growth, which causes a range of undesirable effects, not only on the textile itself, but also on the user [12]. So, there is a great demand for antimicrobial finishes of textiles to control the growth of microorganisms [13]. There are several studies available on usability of different natural dye sources to ensure antibacterial efficiencies. For example, Gupta et al. (2004) were tested eleven natural dyes against three types of Gram-negative bacteria and they were declared that seven of them showed activity against one or more of the tested bacteria [14]. Şapcı et al. (2017) reported antimicrobial and antifungal activity of fabrics dyed with viburnum opulus and onion skins [15]. In other study, Khan et al. (2012) were examined the effect of Rheum emodi L. as dye and its dyed wool yarns against two bacterial and two fungal species. They were declared that the dyed samples showed very effective antimicrobial properties [16]. Likewise, Singh et al. (2005) tested four natural dyes against common pathogens and found Quercus infectoria dye indicating the best antimicrobial activity [17]. 


\section{MATERIAL AND METHODS}

\section{Material}

In the experiments, $100 \%$ woolen fabric was used in a $2 / 1$ twill construction with a weight of $160 \mathrm{~g} / \mathrm{m}^{2}$. The fabrics were in pretreated form and ready for dyeing process so no additional process was conducted prior to dyeing.

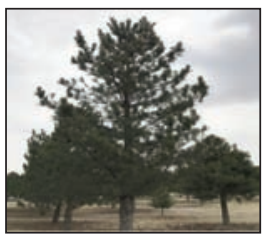

a

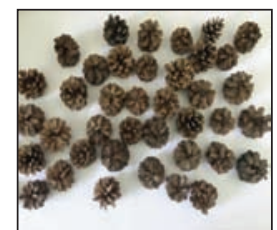

b

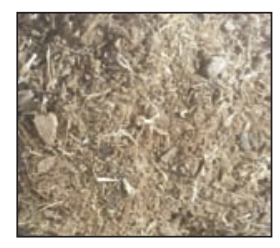

c
Fig. 1. (a) Black pine (Pinus nigra) tree; (b) The cones; (c) The milled cones

As a natural dye source, the idle cones (figure $1, b$ ) of the black pine (Pinus nigra) tree (figure $1, a$ ) that grows in Central Anatolia region is used. The cones were collected and dried up in the shadow after they completed the developmental period and poured. These dried cones were then milled (figure 1, c) and these milled cones were used in the dyeing of the wool fabrics.

\section{Method}

The dyeings were conducted in a laboratory type sample dyeing machine according to exhaustion method. In dyeing procedure firstly the dye bath was adjusted to $\mathrm{pH} 7$ and then the fabric, natural dye source and mordanting agent have been added to this bath as seen from the figure 2 .

The dyeing and mordanting of the fabrics has been managed simultaneously and as mordanting agents; $3 \%$ Copper (II) sulfate $\left(\mathrm{CuSO}_{4} \cdot 5 \mathrm{H}_{2} \mathrm{O}\right.$ ), $3 \%$ tin (II) chlo ride $\left(\mathrm{SnCl}_{2} \cdot 2 \mathrm{H}_{2} \mathrm{O}\right), 3 \%$ iron (II) sulfate $\left(\mathrm{FeSO}_{4} \cdot 7 \mathrm{H}_{2} \mathrm{O}\right)$, $3 \%$ potassium dichromate $\left(\mathrm{K}_{2} \mathrm{Cr}_{2} \mathrm{O}_{7}\right)$ or $20 \%$ Alum $\left(\mathrm{KAl}\left(\mathrm{SO}_{4}\right)_{2} \cdot 12 \mathrm{H}_{2} \mathrm{O}\right)$ have been used. Moreover, dyeings without use of any mordanting agent have been tested too. The natural dye sources used in the experiments were directly added to the dye bath without any previous extraction in three different concentrations: $1: 0.5 ; 1: 1 ; 1: 2$ (fabric to natural dye source ratio). During the dyeing procedure the liquor ratio was adjusted to 1:50 (fabric to dye bath ratio). After the dyeing process, the samples were allowed to dry at room temperature following the washing process

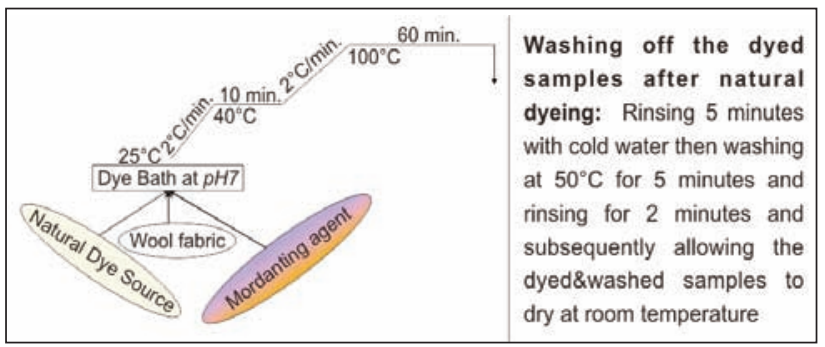

Fig. 2. Natural dyeing procedure and then various measurements were conducted to them.

CIE $L$ * $a{ }^{*} b$ * values and color efficiencies (K/S) of the dyed fabric samples were measured to evaluate the usability of the pine cones as a natural dye source. Konica Minolta 3600d spectrophotometer was used for this purpose. Moreover, the samples were photographed by scanning the samples to better observe the colors obtained. In addition, after dyeings the samples were evaluated for light fastness (according to ISO 105-B02) [18] and washing fastness (according to ISO 105-C10 standard) [19].

Moreover to see the effect of pine cones in terms of the antibacterial activity, the samples dyed with pine cones at the highest dye concentration of the 1:2 have been analyzed in terms of the antibacterial efficiencies.

The antibacterial test method used in this study is described in detail elsewhere [20]. For determination of antibacterial effectsof the fabrics; the naturally dyed samples were tested against Gram-negative bacteria (Escherichia coli ATCC 25922) and Gram-positive bacteria (Staphylococcus aureus ATCC 29213) according to ASTM E 214901 standard [21].

The antibacterial efficiency of the samples was measured by using the equation presented below. This equation represents the bacteria reduction (\%) caused by the contact with the sample for 24 hours.

Bacteria Reduction $(\%)=100 \times\left(B C_{0}-B C_{24}\right) / B C_{0}$

$B C_{24}$ : Bacteria concentration (CFU/ml) of the jar after "24 hours" contact time with the naturally dyed sample.

$B C_{0}$ : Bacteria concentration (CFU/ml) of the jar at "O" contact time (before the addition of the naturally dyed sample).

\section{RESULT AND DISCUSSION}

In order to talk about the usability of any vegetable source in textile dyeing, this source should be able to color the textile materials as competently and exhibit sufficient fastnesses at the same time. In this context, the colors obtained after dyeings in the framework of the experiments were measured firstly and collected in table 1. Table 1 also contains the scanned photos of the samples too.

It was generally seen from the table 1 that the amount of dyestuff used in obtaining different colors is not important and that different colors can not be obtained by changing the amount of pine cone used in dyeing. On the other hand, it has been observed that the color efficiency and the lightness-darkness values $\left(L^{*}\right)$ change with the change in the concentration of the natural dye source. The increase in $L^{*}$ value gives the lightness of the color, while the decrease indicates that the color is darker. The $L^{*}$ value ranged from 48.55 to 79.88 for the samples of woolen fabrics dyed with pine cone. When the $L^{*}$ values were taken into account it was found that a reduction in $L^{*}$ values could come across in case of 


\begin{tabular}{|c|c|c|c|c|c|c|c|c|}
\hline \multicolumn{9}{|c|}{ THE COLORS AND COLOR VALUES OF THE FABRICS DYED WITH PINE CONES } \\
\hline \multirow{2}{*}{$\begin{array}{l}\text { Natural dye } \\
\text { source } \\
\text { concentration }\end{array}$} & \multirow{2}{*}{ Mordanting agent } & \multirow[b]{2}{*}{$\mathrm{K} / \mathrm{S}$} & \multicolumn{5}{|c|}{ CIE L*a*b* (D65) } & \multirow{2}{*}{$\begin{array}{l}\text { Scanned } \\
\text { samples }\end{array}$} \\
\hline & & & $\mathbf{L}^{*}$ & $a^{*}$ & $\mathbf{b}^{*}$ & $\mathbf{C}^{*}$ & $\mathbf{h}^{\circ}$ & \\
\hline 1:0.5 & No mordanting agent & 2.42 & 60.34 & 12.72 & 16.47 & 20.82 & 52.32 & \\
\hline $1: 1$ & No mordanting agent & 3.26 & 57.53 & 13.9 & 18.16 & 22.86 & 52.57 & \\
\hline $1: 2$ & No mordanting agent & 4.21 & 56.81 & 12.78 & 20.58 & 24.23 & 58.15 & \\
\hline \multirow{5}{*}{$1: 0.5$} & Copper (II) sulfate & 7.52 & 52.69 & 5.67 & 24.15 & 24.81 & 76.79 & \\
\hline & Tin (II) chloride & 1.3 & 79.88 & 2.12 & 22.1 & 22.2 & 84.52 & \\
\hline & Iron (II)sulfate & 2.54 & 62.29 & 9.63 & 18.59 & 20.93 & 62.61 & \\
\hline & Potassium dichromate & 2.79 & 65.21 & 5.88 & 21.16 & 21.97 & 74.46 & \\
\hline & Alum & 1.55 & 72.77 & 4.95 & 19.42 & 20.04 & 75.7 & \\
\hline \multirow{5}{*}{$1: 1$} & Copper (II) sulfate & 8.02 & 51.57 & 7.78 & 25.03 & 26.21 & 72.74 & \\
\hline & Tin (II) chloride & 1.85 & 73.65 & 9.05 & 23.05 & 24.76 & 68.56 & \\
\hline & Iron (II) sulfate & 3.83 & 56.73 & 11.88 & 19.57 & 22.89 & 58.75 & \\
\hline & Potassium dichromate & 2.83 & 63.61 & 4.69 & 19.62 & 20.17 & 76.56 & \\
\hline & Alum & 2.06 & 68.7 & 7.34 & 20.38 & 21.66 & 70.2 & \\
\hline \multirow{5}{*}{$1: 2$} & Copper (II) sulfate & 9.57 & 48.55 & 9.67 & 25.27 & 27.06 & 69.05 & \\
\hline & Tin (II) chloride & 2.96 & 69.9 & 6.52 & 25.93 & 26.74 & 75.9 & \\
\hline & Iron (II) sulfate & 4.55 & 56.84 & 10.45 & 21.81 & 24.18 & 64.39 & \\
\hline & Potassium dichromate & 3.24 & 63.26 & 6.59 & 21.98 & 22.95 & 73.32 & \\
\hline & Alum & 2.71 & 65.72 & 7.1 & 22.12 & 23.24 & 72.21 & \\
\hline
\end{tabular}

the increase the used natural dye source concentration in dyeings. This can be shown as proof that the color becomes darker with the increase of used dye concentration. The increase in the K/S value indicates that the color efficiency is high while the decrease shows that the color efficiency is low. The $\mathrm{K} / \mathrm{S}$ value for woolen fabric samples dyed with pine cone varies between 1.30 and 9.57 . When the color efficiencies of the dyed samples were compared, it was found that the $\mathrm{K} / \mathrm{S}$ values increase as the dyeing concentration increases and this tendency is also seen in the dyeings made with different mordanting agents as well. If an example of the dyeing done without use of any mordanting agent want to be given; it could be seen that the color efficiency for the 1:2 dye concentration was 4.21 , and the color efficiency for the dyeing concentration 1:0.5 was 2.42. From table 1 , it can be seen that the variation in dyeing efficien- cy was mainly due to the natural dye source concentration and mordanting agent type. Along with the increase in dyeing concentration, an increase in color efficiency is an expected feature. Moreover, it has been observed that the highest color efficiency could be achieved by using copper (II) sulfate as a mordanting agent and the lowest color efficiencies were generally observed with tin (II) chloride and alum.

On the other hand, the effect of the mordanting agents on obtaining different colors was obvious. When table 1 has been examined, it could be easily seen that different colors and shades can be obtained with the use of different mordanting agents. It was seen from table 1 that yellow, khaki, pinkish orange and brown colors and tones could be obtained in the dyeings made with the use of pine cones. By taking the hue angles $\left(h^{\circ}\right)$ in table 1 as reference, it was determined that the hue angles were 


\begin{tabular}{|c|c|c|c|c|c|c|c|c|c|}
\hline \multicolumn{10}{|c|}{ LIGHT AND WASHING FASTNESSOF FABRICS DYED WITH PINE CONES } \\
\hline \multirow{3}{*}{ Mordanting agent } & \multicolumn{9}{|c|}{ Natural dye source concentration } \\
\hline & \multicolumn{3}{|c|}{$1: 0,5$} & \multicolumn{3}{|c|}{$1: 1$} & \multicolumn{3}{|c|}{$1: 2$} \\
\hline & Light & \multicolumn{2}{|c|}{ Washing } & Light & \multicolumn{2}{|c|}{ Washing } & Light & \multicolumn{2}{|c|}{ Washing } \\
\hline \multirow{2}{*}{ No mordanting agent } & \multirow{2}{*}{$3 / 4$} & C.C. & 5 & \multirow{2}{*}{$3 / 4$} & C.C. & 5 & \multirow{2}{*}{4} & C.C. & 5 \\
\hline & & Sta. & 5 & & Sta. & 5 & & Sta. & 5 \\
\hline \multirow{2}{*}{ Copper (II) sulfate } & \multirow{2}{*}{$3 / 4$} & C.C. & 5 & \multirow{2}{*}{3} & C.C. & 5 & \multirow{2}{*}{4} & C.C. & 5 \\
\hline & & Sta. & 5 & & Sta. & 5 & & Sta. & 5 \\
\hline \multirow{2}{*}{ Tin (II) chloride } & \multirow{2}{*}{4} & C.C. & 5 & \multirow{2}{*}{$4 / 5$} & C.C. & 5 & \multirow{2}{*}{$4 / 5$} & C.C. & 5 \\
\hline & & Sta. & 5 & & Sta. & 5 & & Sta. & 5 \\
\hline \multirow{2}{*}{ Iron (II) sulfate } & \multirow{2}{*}{$3 / 4$} & C.C. & 5 & \multirow{2}{*}{$3 / 4$} & C.C. & 5 & \multirow{2}{*}{$3 / 4$} & C.C. & 5 \\
\hline & & Sta. & 5 & & Sta. & 5 & & Sta. & 5 \\
\hline \multirow{2}{*}{ Potassium dichromate } & \multirow{2}{*}{$3 / 4$} & C.C. & 5 & \multirow{2}{*}{4} & C.C. & 5 & \multirow{2}{*}{4} & C.C. & 5 \\
\hline & & Sta. & 5 & & Sta. & 5 & & Sta. & 5 \\
\hline \multirow{2}{*}{ Alum } & \multirow{2}{*}{4} & C.C. & 5 & \multirow{2}{*}{4} & C.C. & 5 & \multirow{2}{*}{$4 / 5$} & C.C. & 5 \\
\hline & & Sta. & 5 & & Sta. & 5 & & Sta. & 5 \\
\hline
\end{tabular}

Sta.: Staining on wool; C.C.: Color Change

around 52 in all mordant free dyeings. For example, in a mordant free dyeing process at a 1:1 dye concentration, the $h^{\circ}$ was 52.57 , $a^{*}$ was 13.9 and $b^{*}$ was 18.16 and the color is perceived as a pinkish orange. After dyeing at 1:0.5 dye concentration by using copper sulphate mordanting agent, the $\mathrm{h}^{\circ}$ value of the obtained color was 76.79 , and $a^{*}$ and $b^{*}$ values were measured as 5.67 and 24.15 respectively. Therefore, a yellowish and a lesser red color than the color obtained from the mordant free dyeing emerged and a khaki color was observed. In dyeings with tin chloride mordanting agent at 1:0.5 natural dye source concentration, the obtained color was perceived as in light yellow shade. The $a^{*}$ and $b^{*}$ values were measured 2.12 and 22.1 respectively and $h^{\circ}$ angle was found 84.52. As can be seen, different colors and color tones could be obtained with the pine tree cones using different mordanting agents. It is possible to obtain different colors with a single natural dye source, for example herein with pine tree cones, thanks to this unique feature of the natural dyes.

Another important parameter in terms of textile dyeing is the fastnesses, which were also tested for the samples dyed with milled pine tree cones. Table 2 shows the light fastness and wash fastness of the samples.

When table 2 has been examined, it was seen that mordant types and natural dye source concentration were effective in terms of light fastness values. But generally in coloring made by using pine tree cones, the light fastnesses were medium-good. If a generalization is made, it was found that the increase of the natural dye source concentration generally means the increase of the light fastness values. The reason of this was thought to be due to the high tolerability of the dyestuff portion of the light-decayed in dark colors. When the washing fastness values were checked, very good/excellent washing fastness results were obtained. All wash fastness results have a value of 5 for staining and color change. This showed that wool fabrics dyed with pine cone natural dye source have no staining or discoloration during washing process. In other words, it could be said that the mordant material and the dyeing concentration have no effect on washing fastness for dyeing with pine cone natural dye source and that sufficient fastness results could be obtained.

As detailed in the method part of the study, the wool fabrics dyed with pine cones at concentration of 1:2 were analyzed in terms of antibacterial efficiencies against $E$. coli and $S$. aureus. From table 3 , it was observed that there was no bacteria reduction in undyed wool fabrics.

Table 3

THE ANTIBACTERIAL ACTIVITY OF WOOL FABRICS

DYED WITH PINE CONES AT A CONCENTRATION OF $1: 2$

\begin{tabular}{|l|c|c|}
\hline \multirow{2}{*}{} & \multicolumn{2}{|c|}{ Bacteria reduction (\%) } \\
\cline { 2 - 3 } & S. aureus & E. coli \\
\hline Undyed wool fabric & - & - \\
\hline $\begin{array}{l}\text { Wool fabric dyed without use } \\
\text { of any mordanting agent }\end{array}$ & 99.7 & - \\
\hline $\begin{array}{l}\text { Wool fabric dyed with use } \\
\text { of Copper (II) sulfate }\end{array}$ & 99.9 & 99.9 \\
\hline $\begin{array}{l}\text { Wool fabric dyed with use } \\
\text { of Tin (II) chloride }\end{array}$ & 99.9 & - \\
\hline $\begin{array}{l}\text { Wool fabric dyed with use } \\
\text { of Iron (II) sulfate }\end{array}$ & 99.9 & 99.9 \\
\hline $\begin{array}{l}\text { Wool fabric dyed with use } \\
\text { of Potassium dichromate }\end{array}$ & 50 & - \\
\hline $\begin{array}{l}\text { Wool fabric dyed with use } \\
\text { of Alum }\end{array}$ & 99.9 & 99.9 \\
\hline
\end{tabular}


These antibacterial test results clearly showed that depending on the tested bacteria and used mordanting agents the reduction (\%) of the bacteria population has differed but generally it can be told that natural dyeing with pine cones ensured better antibacterial efficiency against S. aureus. As seen from the table 3, except the samples dyed in presence of Potassium dichromate mordanting agent the bacterial reduction of S. aureus is higher than $99 \%$ so not only the effect of the mordanting agents but also the extracts of pine cones have an antibacterial efficiency against $S$. aureus. However when the antibacterial efficiency against Gram-negative bacteria (E. coli) has been examined, it was observed that natural dye source of pine cones have not antibacterial efficiency against E. coli and only if the Copper (II) sulfate, Iron (II) sulfate or alum based natural dyed samples exhibit significant bacterial reduction of E. coli. So this antibacterial efficiency against $\mathrm{E}$. coli is more related to the used mordanting agent and the tested natural dye source solely did not cause a positive effect on it.

\section{CONCLUSIONS}

In this study, it was aimed to show the usability of pine cones in natural dyeing of the wool fabrics. As a result of the dyeing experiments, it has been determined that the pine tree cones can bring out different colors with the use of different mordanting agents. When a summary is made by looking at the generic; the color of pinkish orange was obtained in the mordant free dyeings. Moreover, depending on the type of mordant in the mordant based dyeings; yellowbeige, khaki, pinkish orange and brown tones had been observed. In addition, it was observed that same washing but different light fastnesses can be obtained with the use of different mordanting agents. Beyond the use of pine cones as a natural dye source, the effect of pine cone based natural dyeing has also been analyzed in terms of antibacterial efficiencies. The dyed samples' antibacterial efficiencies were tested against $\mathrm{E}$. coli and $\mathrm{S}$. aureus. It was found that while the fabrics not dyed did not exhibit antibacterial efficiency, the samples dyed with pine cones has shown an antibacterial efficiency depending on the used mordanting agent and the bacteria tested. But briefly, wool fabrics dyed with pine cones in presence of Copper (II) sulfate, Iron (II) sulfate or alum showed antibacterial efficiency for both $\mathrm{E}$. coli and $\mathrm{S}$. aureus and the mordant free dyed samples were showed an antibacterial efficiency against only S. aureus.

\section{BIBLIOGRAPHY}

[1] Christie R.M. Colour chemistry (2 ${ }^{\text {nd }}$ Ed.), In: Royal Society of Chemistry, Cambridge, UK, p. 1, 2015.

[2] Samanta A.K., Konar A. Dyeing of textiles with natural dyes, In: Akçakoca Kumbasar E. P., (Eds.), Natural Dyes, InTech, Croatia, p. 29, 2011.

[3] Jothi D., Extraction of natural dyes from African marigold flower (tagetes ereectal l.) for textile coloration, In: Autex Research Journal, 2008, vol. 8, no. 2, pp. 49-53.

[4] Bechtold T., Mussak R., Mahmud-Ali A., Ganglberger E., Geissler S. Extraction of natural dyes for textile dyeing from coloured plant wastes released from the food and beverage industry, In:Journal of the Science of Food and Agriculture, 2006, vol. 86, issue 2, pp. 233-242.

[5] Sarayu K., Sandhya S. Current technologies for biological treatment of textile wastewater - A review, In: Applied Biochemistry and Biotechnology, 2012, vol. 167, issue 3, pp. 645-661.

[6] O’Neill C., Hawkes F,R., Hawkes D. L., Lourenço N. D., Pinheiro H. M., Delee W. Colour in textile effluents sources, measurement, discharge consents and simulation: A review, In: Journal of Chemical Technology and Biotechnology, 1999, vol. 74, issue 11, pp. 1009-1018.

[7] Samanta A. K., Agarwal P., Application of natural dyes on textiles, In: Indian Journal of Fibre \& Textile Research, 2009, vol. 34, no. 4, pp. 384-399.

[8] Sivacioglu A., Ayan S. Variation in cone and seed characteristics in a clonal seed orchard of Anatolian black pine (pinus nigra Arnold subsp. pallasiana (lamb.) Holmboe), In: Journal of Environmental Biology, 2010, vol. 31, no. 1, pp. 119-123.

[9] Gülçin İ., Büyükokuroğlu M. E., Oktay M., Küfrevioğlu İ. Antioxidant and analgesic activities of turpentine of pinus nigra arn. subsp. pallsiana (lamb.) holmboe, In: Journal of Ethnopharmacology, 2003, vol. 86, issue 1, pp. 51-58.

[10] Demirak A., Keskin F., Şahin Y., Kalemci V. Removal of ammonium from water by pine cone powder as biosorbent, In: Mugla Journal of Science and Technology, 2015, vol. 1, no.1, pp. 5-12.

[11] Orhan M., Kut D., Gunesoglu C. Improving the antibacterial activity of cotton fabrics finished with triclosan by the use of 1,2,3,4-butanetetracarboxylic acid and citric acid, In: Journal of Applied Polymer Science, 2009, vol. 111, issue 3, pp. 1344-1352.

[12] Morais S.A., Guedes R.M., Lopes M.A. Antimicrobial approaches for textiles: from research to market, In: Materials, 2016, vol. 9, issue 6, pp. 1-21.

[13] Xing Y., Yang X., Dai J. Antimicrobial finishing of cotton textile based on water glass by sol-gel method, In: Journal of Sol-Gel Science and Technology, 2007, vol. 43, issue 2, pp. 187-192. 
[14] Gupta D., Khare S.K., Laha A. Antimicrobial properties of natural dyes against gram-negative bacteria, In: Coloration Technology, 2004, vol. 120, issue 4, pp. 167-171.

[15] Şapcı, H., Yılmaz, F., Vural, C., Bahtiyari, M.İ., Benli, H. Antimicrobial and antifungal activity of fabrics dyed with viburnum opulus and onion skins, In: International Journal of Secondary Metabolite, 2017, vol. 4, no. 3, pp. $280-284$.

[16] Khan, S.A., Ahmad, A., Khan M.I., Yusuf M., Shahid M., Manzoor N., Mohammad F. Antimicrobial activity of wool yarn dyed with rheum emodi I. (indian rhubarb), In: Dyes and Pigments, 2012, vol. 95, issue 2, pp. $206-214$.

[17] Singh, R., Jain, A., Panwar, S., Gupt,a D., Khare, S.K., Antimicrobial activity of some natural dyes, In: Dyes and Pigments, 2005, vol. 66, issue 2, pp. 99-102.

[18] ISO 105-B02:1994 Textiles - Tests for color fastness - Part B02: Color fastness to artificial light: Xenon arc fading lamp test, International Organization for Standardization, Geneva, Switzerland, 1994.

[19] ISO 105-C10:2006 Textiles - Tests for color fastness - Part C10: Color fastness to washing with soap or soap and soda, Test Condition: Test A(1), International Organization for Standardization, Geneva Switzerland, 2006.

[20] Beşen, B.S., Balcı, O., Güneşoğlu, C., Orhan, M., Somuncuoğlu, E.I., Tatlı, İ.I. Obtaining medical textiles including microcapsules of the ozonated vegetable oils, In: Fibers and Polymers, 2017, vol. 18, issue 6, pp. 1079-1090.

[21] ASTM E2149-01 Standard Test Method for Determining the Antimicrobial Activity of Immobilized Antimicrobial Agents Under Dynamic Contact Conditions, ASTM International, USA, 2001.

\section{Authors:}

\section{IBRAHIM BAHTIYARI \\ FAZLIHAN YILMAZ}

Erciyes University, Textile Engineering Department, Melikgazi, Kayseri, Turkey

e-mail: bahtiyari@erciyes.edu.tr; fazlihanyilmaz@erciyes.edu.tr

Corresponding author:

M. IBRAHIM BAHTIYARI

e-mail: bahtiyari@erciyes.edu.tr

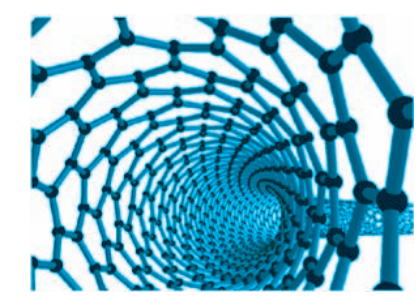

